\title{
Reflections on the Academic Senate Resolution ${ }^{\dagger}$
}

\author{
Robert M. O'Neil*
}

W HATEVER ELSE may be said of it, the resolution adopted on December 8,1964 , by the Berkeley faculty was certainly controversial. No sooner did it quell the storm on the campus than it provoked a new storm off the campus. "A Faculty Bows to Anarchy," cried one Southern California newspaper in bitter denunciation. ${ }^{1}$ At the same time, a distinguished department chairman spoke for many of his Berkeley colleagues when he praised the Senate for upholding "the highest ideals of university education and political life." Attack and defense in a similar vein pervaded the state for some months thereafter. ${ }^{3}$

During the fifteen months since December 8, debate at Berkeley has become more reflective, while the issues raised by the faculty resolution have assumed national significance. This past year has stimulated careful consideration and thoughtful discussion of the underlying issues of educational policy, which affect virtually every large public college and university. Largely neglected, however, have been the very difficult legal questions raised by the resolution. Those questions deserve much more elaborate analysis than they will receive here. What this comment will attempt is to highlight several of the major questions which bring together law and university administration at their major points of interaction-or, as some would say, of collision.

One must recognize at the outset several factors which make any legal analysis of the Berkeley faculty resolution a treacherous undertaking: First, the majority of its draftsmen and active supporters were not lawyers. These laymen were presumably unaware of the extent to which they were making legal judgments; nor were they conscious of

$\dagger$ This comment has profited considerably from a careful reading by Professor Hans Linde of the University of Oregon School of Law, who was my colleague at Berkeley during the events which inspired this symposium.

* A.B., 1956, A.M., 1957, LL.B., 1961, Harvard University; Acting Associate Professor of Law, University of Cahfornia, Berkeley.

1 Quoted fron the Santa Monica Evening Outlook of December 10, 1964, in Revorutron AT BERKELEY 339 (Miller \& Gilmore eds. 1965).

2 Statement of Professor Philip Selznick, Chairman of the Department of Sociology, University of California, Berkeley, in A Message on the Proposed Solution to the Free Speech Controversy 2 (1964).

3 For charges and countercharges in the press during the months after December 8, see generally REvolUTion AT BERKELEY, op. cit. supra note 1, at 336-48. A wealth of relevant material on this and other aspects of the Berkeley experience may be found in TrE BERKELEY StUdENT Revort 252-431 (Lipset \& Wolin eds. 1965). 
the relevant case-law background. Second, the resolution was drafted hastily, under intense pressure from all sides, and was passed with virtually no legislative history to explam its subtleties or to guide subsequent interpretation. Fimally, the precise legal character of the resolution requires a brief explanation. Since the Academic Senate cannot finally determine, but can only recommend, University policy, its actions are not truly legislative. Y.et because of the deference which a wise university administration pays to strong faculty sentiment on such nuatters, the Senate's resolution is more than a mere suggestion or abstract proposal. Although the University's Regents did not completely ratify the faculty's position at its December 1964 neeting, that body was unquestionably influenced by the resolution in fashioning its new code of student conduct and rules for campus political activities. Thus the technically "advisory" capacity of the Senate does not betoken impotence in the formulation of this or other vital university policies.

The terms of the resolution nust be imderstood at the outset. The faculty vote of December 8 armounced four essential principles: ${ }^{4}$ (1) The "content of speech or advocacy should not be restricted by the University"; (2) off-campus student political activity should be immune from university regulation, with on-campus advocacy of such activity regulated only as to time, place, and manner; (3) political activities on the campus should be governed by reasonable regulations of time, place,

4 The text of the Academic Senate resolution, as adopted on December 8, 1964, by a vote of 824 to 115 , is as follows:

In order to end the present crisis, to establish the confidence and trust essential to the restoration of normal University life, and to create a campus environment that encourages students to exercise free and responsible citizenship in the University and in the community at large, the Committee on Academic Freedon of the Berkeley Division of the Academic Senate moves the following propositions:

1. That there shall be no University disciplinary measures against members or organizations of the University community for activities prior to December 8 connected with the current controversy over pohitical speech and activity.

2. That the time, place, and manner of conducting political activity on the campus shall be subject to reasonable regulation to prevent interference with the normal functions of the University; that the regulations now in effect for this purpose shall remain in effect provisionally pending a future report of the Contmittee on Academic Freedon concerning the minimal regulations necessary.

3. That the content of speech or advocacy should not be restricted by the University. Off-campus student political activities shall not be subject to University regulation. On-campus advocacy or organization of such activities shall be subject only to such limitations as may be imposed under section 2.

4. That future disciplinary measures in the area of pohitical activity shall be determined by a committee appointed by and responsible to the Berkeley Division of the Academic Senate.

5. That the Division urge the adoption of the foregoing policies and call on all members of the University community to join with the faculty in its efforts to restore the University to its normal functions. 
and manner "to prevent interference with the normal functions of the University"; and (4) any discipline concerning student political activities "shall be determined by a committee appointed by and responsible to" the Academic Senate. The last principle has been only partially implemented, and will not be discussed lere. Our attention will focus upon the other three principles and some of the legal questions they raise.

I

\section{PRELIMINARY ASSUMPTIONS AND DISTINCTIONS}

The resolution implicitly assumes two vital legal principles: first, that a public university is constitutionally compelled to inake its facilities available for free expression and public debate; and second, that attendance at a public college or university may not be conditioned upon the surrender of liberties and privileges generally enjoyed by students as citizens outside the campus. Any appreciation of the legal foundation of the resolution requires discussion of both assumptions.

There is no longer any doubt that for such purposes as hiring and admissions, the state university is as mucl subject to the fourteenth amendment as other branches of the state government. ${ }^{5}$ While the state is under no constitutional obligation to create a public university at all and, if it does so, incurs no obligation to hire or admit any particular person, it may not refuse to employ or admit on the basis of race, religion, nationality, or any other discriminatory standard. ${ }^{\circ}$ What is less clear is how inuch freedom of speech is constitutionally required on the public campus. Even in the outside community the right to speak is less absolute than the right not to be disadvantaged by government action on racial or religious grounds. ${ }^{7}$ It is still uncertain, for example, whether a town or city unust make any of its facilities available for speeches, rallies,

5 See, e.g., McLaurin v. Oklahoma State Regents, 339 U.S. 637 (1950); Sweatt v. Painter, 339 U.S. 629 (1950); Sipuel v. Board of Regents, 332 U.S. 631 (1948); Missouri ex rel. Gaines v. Canada, 305 U.S. 337 (1938).

BEven some private, or semi-private, colleges and universities may be subject to the limitations of the fourteenth amendment. Although a suggestion to that effect regarding Tulane University, Guillory v. Administrators of Tulane Univ., 203 F. Supp. 855 (E.D. La. 1962), was later overruled in Guillory v. Administrators of Tulane Univ., 212 F. Supp. 674, 677 (E.D. La. 1962), the recent decision in Hammond v. University of Tampa, 344 F.2d 951 (5th $\mathrm{Cir}$. 1965), imdicates the circumstances under which private universities may become subject to the fourteenth amendment by receipt of public funds and other governmental benefits. Such questions may also arise obkquely. See, e.g., Emory University v. Nash, 218 Ga. 317, 127 S.E.2d 798 (1962); cf. Evans v. Newton, 86 Sup. Ct. 486 (1966).

7 Cases such as Cooper v. Aaron, 358 U.S. 1 (1953), and Watson v. Memphis, 373 U.S. 526 (1963), indicate that even the narrow qualifications placed upon the rights of free expression (e.g., "clear and present danger" limitations) do not apply to claims of denial of equal protection of the laws. 
or parades ${ }^{8}$-quite apart from the undoubted obligation to act fairly and evenly if it does choose to make them available for any such purpose.

Beyond that, the university campus is clearly less "public" than the village square or public park. Like the public library and county hospital, the umversity must be able to control noise and maimtain the flow of traffic in order to protect those who work and study in its laboratories, offices, and classrooms. Yet the student or faculty member at the state university needs some public forum on the campus to present effectively a controversial message to the rest of the academic community. This is particularly the case in the small college town, where alternative facilities may be simply unavailable. But even in Berkeley, Columbus, Madison, or Ann Arbor, where general community facilities do exist, there is strong constitutional support for the principle espoused by the Berkeley faculty-that the state university must provide some reasonable opportunity on the campus for political activities, however controversial or unsettling they may appear either to the administration or to the outside community. ${ }^{10}$

8 There was a time when towns and cities were considered to incur no legal obligation to make such facilities available. Davis v. Massachusetts, 167 U.S. 43, 48 (1897). For a more recent division of opinion on that question, compare Kovacs v. Cooper, 336 U.S. 77, 97-98 (1949) (concurring opinion); Kunz v. New York, 340 U.S. 290, 298 (1951) (dissenting opinion); Cox v. Louisiana, 379 U.S. 536, 578, 581 (1965) (opinion of Black, J.), with Neimotko v. Maryland, 340 U.S. 268, 282-83 (1951) (separate opinion of Frankfurter, J.); Hague v. CIO, 307 U.S. 496, 515-16 (1939) (opinion of Roberts, J.). The question was recently considered, but expressly left open, in Cox v. Louisiana, 379 U.S. 536, 555 \& n.13 (1965). For a valuable recent discussion of the question, see also Rockwell v. Morris, 12 App. Div. 2d 272, 277-83, 211 N.Y.S.2d 25, 32-36, af'd mem., 10 N.Y.2d 721, 176 N.E.2d 836, 219 N.Y.S.2d 268, cert. denied, 368 U.S. 913 (1961).

During the late 1940's and early '50's, there was considerable discussion of this question in the legal literature. See, e.g., Abernathy, Assemblies in the Public Streets, 5 S.C.L.Q. 384 (1953); Murphy, Free Speech and the Interest in Local Law and Order, 1 J. PuB. L. 40 (1952); Comment, Municipal Regulation of Free Speech in the Streets and Parks, 46 IrI. L. Rev. 489 (1951); Comment, Free Speech and the Right of Municipalities To Regulate the Use of Public Places, 19 U. Kav. CITY L. Rev. 191 (1951); Comment, Municipal Control of Public Streets and Parks As Afjecting Freedom of Speech and Assembly, 49 Mrcm. L. Rev. 1185 (1951); Note, Freedom of Speech and Assembly: The Problem of the Hostile Audience, 49 Color. L. Rev. 1118 (1949); Note, Freedom of Speech and Assembly int Streets and Other Public Places, 19 Geo. Wasr. L. Rev. 637 (1951). Recent comments, of which there have been rather few, have been devoted to more specialized aspects of the problem, such as the question of access to college and university campuses, with which we are concerned here.

${ }^{2}$ See, e.g., Fowler v. Rhode Island, 345 U.S. 67 (1953); cf. Canon v. Justice Court, 61 Cal. 2d 446, 393 P.2d 428, 39 Cal. Rptr. 228 (1964).

10 See, e.g., Danskin v. San Diego Unified School Dist., 28 Cal. 2d 536, 547, 171 P.2d 885, 892 (1946) ; Buckley v. Meng, 35 Misc. 2d 467, 475-76, 230 N.Y.S.2d 924, 934-35 (Sup. Ct. 1962); cf. Egan v. Moore, 20 App. Div. 2d 150, 245 N.Y.S.2d 622 (1963). These cases suggested, to be sure, that a state educational institution might choose to deny all use of its facilities at least to off-campus or outside speakers. Such suggestions have been questioned 
A caveat is in order at this point: The distinction between "oncampus" and "off-campus" activities, which has preoccupied participants in the Berkeley controversy, has both an artificial and a parochial quality. Even at other branches of the University of California-notably the Los Angeles branch-it is impossible to isolate from the community a geographical enclave containing the university "campus." In many universities, as at U.C.L.A., the very fact that public thoroughfares bisect university property prevents such isolation. While activities occurring on a public street running through the campus may well affect the university's interests more directly than similar activities occurring downtown, the university may be unable to regulate them any more extensively. Even at Berkeley, the artificiality of the distinction is apparent; all sides recognized in the fall of 1964 that the university administration lacked the kind of jurisdiction over political activities on adjacent public sidewalks that it had over activities within the borders of the campus. Thus if the principles derived from the Berkeley experience are to be given wider currency, the rigidity of the on-campus, off-campus dichotomy must be relaxed. ${ }^{11}$

There is, however, at least one additional qualification. Apart from the obvious interests in quiet and orderly movement of traffic, shared with libraries and hospitals, the umiversity has certain special interests which justify regulations of a different character. Such special imterests are both academic and nonacademic. The academic interests include, for example, the power to punish cheating on examinations, plagiarism, and

on constitutional grounds in two recent and penetrating comments. Pollitt, Campus Censorship: Statute Barring Speakers From State Educational Institutions, 42 N.C.L. REv. 179 (1963); Van Alstyne, Political Speakers At State Universities: Some Constitutional Considerations, 111 U. PA. L. REv. 328 (1963). The suggestion has also been questioned on policy as well as legal grounds in American Civin Liserties UnIon, ACAdEMac FreEdom and Crum Liberites of Students in Colleges and Universities 9 (rev. ed. 1965). The most recent controversy concerning this issue has taken place in Nortb Carolina, where a 1963 statute prohibited all Communist speakers on state university and state college campuses. The law was substantially revised on November 17, 1965. But the surviving version of the statute vests in the board of trustees the authority to determine what speakers shall be allowed on the campuses. N.Y. Times, Nov. 18, 1965, p. 23, cols. 5-8. Predictably, this newly delegated power has provided the basis for refusing to permit on the campus not only a speaker who would have been banned by the old statute-Communist Party spokesman Herbert Aptheker-but even a speaker who presumably would have been eligible under the 1963 law-Frank Wilkinson, national chairman of the Committee to Abolish the House Un-American Activities Committee. San Francisco Chronicle, Feb. 8, 1966, p. 18, col. 3. The delegation of such seemingly hroad discretion creates new constitutional problems in the process of solving the old ones. Cf. Saia v. New York, 334 U.S. 558 (1948); Cantwell v. Connecticut, 310 U.S. 296, 305 (1940).

11 For a deeper analysis of the difficulties in applying the on-campus, off-campus distinction to the range of problems subject to university regulation, see Iinde, Campus Law: Berkeley Viewed from Eugene, supra in this symposium. 
unsatisfactory written work. The special nonacademic interests derive largely from the university's guardianship of minors and young adults, and traditionally warrant special protections against such dangers as financial fraud, exposure to gambling, liquor, and narcotics.

Most rules based upon these special regulatory interests are of the "sex, beer, and cheating" variety. Such rules seldom inhibit freedom of expression to any significant degree. Yet occasional implementation of these special interests may raise difficult constitutional questions which are nevertheless resolved in favor of university regulation. Recently, for example, some state universities have banned national fraternity affiliation and even the existence on campus of any social fraternities. These prohibitions have been held valid, ${ }^{12}$ though similar restraints on freedom of association would be invalid outside the campus. ${ }^{13}$ The difference must derive from the university's strong special interest in regulating the living accommodations and residential environment of its students. Another example, this time from the academic side of the university, may reinforce the point: A foreign language instructor will frequently forbid his students to read the English translation of a book while it is being studied in the original version. Such a prohibition would be unenforceable off the campus unless the book came within one of the very narrow categories of legally bannable publications. ${ }^{14}$ But the university's special academic interests presumably justify such drastic curtailment of the students' freedom to read. Thus the special regulatory powers of a public university may occasionally warrant more than incidental imterference with freedom of expression and association, even though the first amendment apphes as much to the campus as to the outside community.

The other implicit assumption of the faculty resolution is the viability

12 Webb v. State Univ. of N.Y., 125 F. Supp. 910 (N.D.N.Y. 1954); Beta Sigma Rho, Inc. v. Moore, 46 Misc. 2d 1030, 261 N.Y.S.2d 658 (Sup. Ct. 1965). It should be noted, however, that neither case squarely raised the first amendment claims of students directly affected by the prohibition, because plaintiffs in both cases were fraternal organizations chiefly concerned with proprietary interests rather than freedom of expression. Had the free speech and association question been squarely presented, and had it been shown that the undoubtedly laudable purpose of banning racial or rehigious discrimination on campus could have been achieved by less drastic means, the umversity might have been constitutionally required to regulate rather than abolish the discriminatory organizations and their offending practices. See Acacia Fraternity v. University of Cal. Regents, 10 CrvII LIBERTIES Docker 71 (1964) (Los Angeles County Super. Ct. Inglewood Div. SWC 5042, Aug. 11, 1964) (plaintiffs, fraternity chapters on university campuses, sued to enjoin defendant from enforcing pohicy of nondiscrimination in campus living accommodations; superior court issued, then dissolved temporary restraining order); IO CTVII LIBERTIES DOCKET 125 (1965) (court sustained defendant's demurrer without leave to amend).

18 See NAACP v. Alabama ex rel. Patterson, 357 U.S. 449 (1958).

14 See Bantam Books, Inc. v. Sullivan, 372 U.S. 58 (1963). 
of the doctrine of "unconstitutional conditions." There was a time when attending college was said by the courts to be a bare "privilege," and students could be dismissed without formal charges or a hearing for such activities as refusal to participate in R.O.T.C. drill, or writing to the local newspaper a letter critical of the college administration. ${ }^{16}$ The public university continues to exercise extensive powers over student admissions and expulsions; so long as a fair hearing is afforded, the courts will seldom challenge the substantive grounds for the dismissal unless they are claimed to be patently unconstitutional. ${ }^{10}$ But there has been a gradual change in the scope of judicial inquiry into student dismissals, probably for two reasons: One is the steady development in other contexts of the doctrine of unconstitutional conditions, ${ }^{17}$ suggesting that a university may not constitutionally condition attendance upon the strrender of liberties of religion or expression which could not be suppressed by the criminal law. The other factor is the changing concept of ligher education. What was once considered a "luxury" is increasingly regarded as a "necessity," and that change has influenced many branches of the law which are concerned with higher education. ${ }^{18}$ Because of these two developments, a surrender of the citizen's right to participate in controversial political activities can no longer be made the price of admission to or continued attendance at a public university.

15 For the attitude of the courts characteristic of cases in the nineteenth and carly twentieth centuries, see, e.g., North v. Board of Trustees, 137 Ill. 296, 306, 27 N.E. 54, 56 (1891); Samson v. Trustees of Columbia Univ., 101 Misc. 146, 150-51, 167 N.Y. Supp. 202, 205 (Sup. Ct. 1917). Traces of such judicial attitudes are still found in the opinions of courts which are reluctant to review internal university affairs. E.g., Steier v. New York State Educ. Comm'r, 271 F.2d 13 (2d Cir. 1959), cert. denied, 361 U.S. 966 (1960); Due v. Florida A. \& M. Univ., 233 F. Supp. 396 (N.D. Fla. 1963).

${ }^{16}$ The background and history of this problem have been summarized in a number of places. See particularly Van Alstyne, Student Academic Freedom and the Rule-Making Powers of Public Universities: Some Constitutional Considerations, 2 LAW IN Transirron Q. 1, 2-6 (1965); Note, The College Student and Due Process in Disciplinary Proceedings, 1962 U. ILL. L. ForUM 438, 439-41.

${ }^{17}$ See Sherbert v. Verner, 374 U.S. 398, $404 \&$ n.5 (1.963); Steinberg v. United States, 163 F. Supp. 590 (Ct. Cl. 1958); American Civil Liberties Union v. Board of Educ., $55 \mathrm{Cal}$. 2d 167, 359 P.2d 45 (1961); Syrek v. California Unemployment Ins. Bd., 54 Cal. 2d 519, 354 P.2d 625 (1960); Emerson, Toward A General Theory of the First Amendment, 72 YaLE L.J. 877, 942-43 (1963); French, Unconstitutional Conditions: An Analysis, 50 Gro. L.J. 234 (1961); Willcox, Invasions of the First Amendment Through Conditioned Public Spending, 41 CORNerl L.Q. 12 (1955); Note, Unconstitutional Conditions, 73 HARV. L. REv. 1595, 1599-1602 (1960). For suggestions about the applicability of these principles to the rights of students, see Monypenny, Toward A Standard Academic Freedom, 28 LAw \& Contemsp. ProB. 625, 627-29 (1963).

18 For a discussion of the changing character of higher education, and the significance of this change for the rights of students, see Van Alstyne, Student Academic Freedom and the Rule-making Powers of Public Universities: Some Constitutional Considerations, 2 Law in Transirion Q. 1, 6-8 (1965). 
In addition to these two assumptions, the resolution implies several distinctions which should be explored before going further. There is obviously an important difference between the university's ability to control the behavior of students and of nonstudents on the campus. In disciplining the student, the university lias a full arsenal of sanctions, ranging from simple physical transfer of offenders-for example, to another section of a large course or another dormitory-all the way to the ultimate sanction of dismissal or expulsion. These last penalties are very drastic indeed. Probably most modern college students would rather pay a heavy fine or even serve a jail sentence than be expelled. Yet we often assume that because the university does not impose "criminal" penalties, certain safeguards which are required in the criminal courts are unnecessary in disciplinary hearings. This assumption requires careful reassessment in light of the changing character of higher education, and of student attitudes toward the value of membership in the academic community. ${ }^{10}$ The nonstudent, by contrast, can only be asked to leave the campus if he violates university rules. This can be done, of course, with varying degrees of coercion, including invoking the assistance of the local pohice.

The distinction between "student" and "nonstudent" poses difficult problems in another area as well. Must the university make its facilities equally available to speakers from off the campus and speakers from within the campus community? The history of University of California

10 Commentators have become increasingly concerned about the fairness of procedures employed in student disciplinary cases. Probably the first such modern concern was expressed in Seavey, Dismissal of Students: "Due Process," 70 HaRv. L. Rev. 1406 (1957). Later comments on this problem include Johnson, The Constitutional Rights of College Students, 42 Texas L. REv. 344 (1964); Van Alstyne, Procedural Due Process and State University Students, 10 U.C.L.A.L. REv. 368 (1963); Note, 1962 U. III. L. ForUM 438; Note, Private Government on the Campus-Judicial Reviezv of University Expulsions, 72 YALE L.J. 1362 (1963).

The attitudes of the courts on this question are less clear, although a few recent cases have required adherence to certain procedures in dismissal cases. E.g., Dixon v. Alabama State Bd. of Educ., 294 F.2d 150 (5th Cir. 1961); Connelly v. University of Vt., 244 F. Supp. 156 (D. Vt. 1965); Knight v. Board of Educ., 200 F. Supp. 174 (M.D. Tenn. 1961). In several other recent cases, federal courts have at least inquired into the fairness of procedures employed in dismissal cases. E.g., Dunmar v. Ailes, 348 F.2d 51 (D.C. Cir. 1965); Steier v. New York State Educ. Comm'r, 271 F.2d 13 (2d Cir. 1959), cert. denied, 361 U.S. 966 (1960); Due v. Florida A. \& M. Univ., 233 F. Supp. 396 (N.D. Fla. 1963).

There have been several recent attempts to formulate procedural criteria for student disciphinary proceedings-apart from those of particular institutions. E.g., AMERICAN CIVIr,

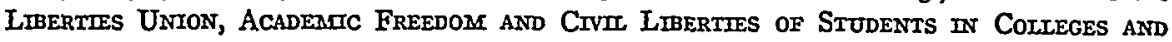
UnIVersitres 12-13 (rev. ed. 1965); Committee S of the American Ass'n of University Professors, Statement on the Academic Freedom of Students, 51 AAUP BULL. 447 (1965). One law review has recently proposed a model statute dealing with many questions of procedural rights of students. Legislation: College Disciplinary Proceedings, 18 VAND. L. REv. 819, 824-30 (1965). 
regulation of the range of permissible off-campus speakers indicates that the University administration has not always thought so. ${ }^{20}$

On the one hand, the University may presumably require at least that a speaker from off the campus identify himself to the administrative authorities, and perhaps secure a permit to speak. Were this requirement administered in the same way that a city administers its parks and open spaces-under a narrow standard admitting of neither discretion nor discrimination based on the content of speech-no constitutional objections would arise. ${ }^{21}$

When more regulation is sought, additional problems are posed. The university community constitutes an audience which speakers of all persuasions desire to reach. If equally effective alternative facilities for reaching the same audience are unavailable, and if the university conditions or denies the outside speaker's access to the campus, the freedom of "effective speech" is curtailed. ${ }^{22}$ On the other hand, the university has a valid educational objective in controlling and regulating the use of scarce "on-campus" speech facilities.

The courts might well develop a test from the line of labor cases that make a showing of the unavailability of alternative facilities a prerequisite to going upon private premises. ${ }^{23}$ The inclination of the California Supreme Court to regard this freedom of access as a part of the general constitutional guarantee of free speech suggests the general applicability of such a standard. ${ }^{24}$ The public university's interest in its "property" may be little stronger than that of a supermarket operator in keeping his parking lots and sidewalks "private." And, to the extent that a university constitutes a "community" within the meaning of the "company

20 See Heirich \& Kaplan, Yesterday's Discord, California Monthly, Feb. 1965, pp. 24, $27,29,32$.

21 See Saia v. New York, 334 U.S. 558 (1947); Thonas v. Collins, 323 U.S. 516 (1945); Cantwell v. Connecticut, 310 U.S. 296 (1940).

22 Cf. Schwartz-Torrance Inv. Corp. v. Bakery Workers' Union, 61 Cal. 2d 766, 394 P.2d 921, 40 Cal. Rptr. 233 (1964); Wollam v. City of Palm Springs, 59 Cal. 2d 276, 379 P.2d 481, 29 Cal. Rptr. 1 (1963). In Cox v. Louisiana, 379 U.S. 536, 555 (1965), the Court reserved the question whether a city nay close all its parks and streets to public expression. The answer to this reserved question is suggested by Marsb v. Alabama, 326 U.S. 501 (1946), which stresses the rights of hearers as well as those of speakers.

${ }^{23}$ See Marshall Field \& Co. v. NLRB, 200 F.2d 375 (7th Cir. 1953); Schwartz-Torrance Inv. Corp. v. Bakery Workers' Union, supra note 22; In re Zerbe, 60 Cal. 2d 666, 388 P.2d 182, 36 Cal. Rptr. 286 (1964).

${ }^{24}$ See Schwartz-Torrance Inv. Corp. v. Bakery Workers' Union, 61 Cal. 2d 766, 394 P.2d 921, 40 Cal. Rptr. 233 (1964); In re Zerbe, supra note 23; of. Wollam v. City of Palm Springs, 59 Cal. 2d 276, 379 P.2d 481, 29 Cal. Rptr. 1 (1963); In re Porterfield, 28 Cal. 2d 91, 168 P.2d 706 (1946). 
town" cases, ${ }^{25}$ the interests of inhabitants in hearing ${ }^{26}$ and visitors in speaking are correspondingly enhanced.

The student-nonstudent distinction suggests a closely related point: Some student transgressions violate only university rules (for example, cheating on examinations, failure to attend classes, and entertaining in the dormitory after hours). Such conduct is of no concern to the general criminal law. Other violations are, however, contrary to the general law as well as university rules (for example, stealing books from the library, serving liquor to minors, and gambling in university buildings). For violations of the first sort, there is no question as to which authority should punish, because only the university is in a position to do so. Offenses of the second type raise, however, two important additional issues: (1) Which authority-the university or the criminal courts-should impose the sanctions? (2) If both are to proceed against the offender, which ought to have priority? While both questions have been central to the Berkeley controversy, they can only be noted here without discussion. (These questions are discussed in the article by Professor Arthur Sherry appearing in this symposium.)

Finally, any discussion of regulation of student behavior must consider the relationship between violative conduct and those special regulatory interests of the university which we have already mentioned. To some extent, the relevance of conduct to these interests is simply a matter of geography; obviously the university has less concern with a student's rowdy behavior at a European summer resort than in the dormitory dining lall. But the distinction is far subtler than this. The relationship of the particular student conduct to disciphinary power should be judged in terms of the whole spectrum of university regulatory interests. Thus the university's claim to penalize student conduct, whether on or off the campus, should vary in direct proportion to: (1) the general strength or importance to the academic community of the special regulatory interests which that conduct offends; (2) the relevance of the particular conduct to these interests; and (3) the difficulty of vindicating those interests by resort to nonpunitive sanctions. ${ }^{27}$ Such a formula would

25 E.g., Marsh v. Alabama, 326 U.S. 501 (1946); Tucker v. Texas, 326 U.S. 517 (1946); see note 22 supra.

${ }^{26}$ The freedom to receive information, first alluded to in Marsh v. Alabama, has been developed in Lamont v. Postmaster General, 381 U.S. 301 (1965).

27 The basis of this third proposition is that doctrine of the "least onerous alternative" in state regulation of federally protected activity. This doctrine should apply with particular force in first amendment cases, as the United States Supreme Court has increasingly suggested in a number of cases thoroughly reviewed in Wormuth \& Mirkin, The Doctrine of the Reasonable Alternative, 9 UTAE L. REV. 254, 267-93 (1964). For example, in striking down a county charter provision barring political activity by county civil servants, the California 
be little affected by the "seriousness" of the offense under the general law. Noncriminal activity involving a fellow student some distance from the campus might thus be more amenable to university discipline than criminal activity very near the campus involving no other members of the academic community. ${ }^{28}$

\section{II}

MEANING OF "THE - CONTENT OF SPEECH"

The resolution declares that "the content of speech or advocacy should not be restricted by the Umiversity." That declaration presents two questions for discussion here: (1) What does this proposition mean? (2) Is it sound as a matter either of policy or of constitutional law? There are several plausible definitions of the central term "content of speech or advocacy." Literally construed, the phrase might mean that the university should never impose any sanction, prior or subsequent, upon any form of communication or expression on the campus. But even the first amendment does not go so far, and there is no indication the faculty meant to immunize expression which is not judged to be "speech" off the campus. There are many illegal activities, for example, which involve extensive oral and written communication, but which are not for that reason constitutionally immune from prosecution. A criminal conspiracy, or solicitation to commit a crime, for instance, would be impossible to consummate without using speech, yet prosecutions for such activities raise no first amendment questions. It seems unlikely,

Supreme Court recently observed: "It must appear that restrictions imposed by a governmental entity are not broader than are required to preserve the efficiency and integrity of its public service." Fort v. Civil Service Comm'n, 61 Cal. 2d 331, 338, 392 P.2d 385, 389, 38 Cal. Rptr. 625, 629 (1964).

28 There is at least a suggestion that relevance to special university interests is a prerequisite to serious disciplinary action, in Knight v. State Bd. of Educ., 200 F. Supp. 174, 181 (M.D. Tenn. 1961). That case involved the review of suspension of several students at a predominantly Negro state-supported college as a result of their participation in racial demonstrations ("freedom rides") in another state. The court expressed concern that the University had not considered the precise nature of the criminal charges brought against the students in the other state. "But even if the charge itself had been before the committee," the court continued, "it would have conveyed very httle information as to what the plaintiffs had actually done and at best would have left a serious doubt as to whether the plaintiffs had been guilty of such misconduct as would reflect dishonor or discredit upon the University." Id. at 181. With regard to student involvement in off-campus political activities, the AAUP Committee S Statement takes the position that "only where the institution's interests as an academic community are distinct from those of the general community should the special authority of the institution be asserted." Statement on the Academic Freedom of Stidents, 51 AAUP BULI. 447, 449 (1965). Tlie Code of Student Conduct of the University of Oregon, for example, requires as the basis of student discipline a showing of a direct relationship between the particular student behavior and the university's special regulatory interests. See Linde, Campus Law: Berkeley Viewed From Eugene, supra in this symposium. 
therefore, that even a strict construction of the phrase "content of speech" would prevent the university froin penalizing a student for unsatisfactory or dishonest written work.

At the other extreme, the Senate might lave intended to permit the Umiversity to punish freely all speech which is punishable under the general law, but no more. Thus a student could be disciplined for advocacy that posed a clear and present danger to public order, or for the distribution of pornographic hterature, or the use of "fighting words." But if this were all the resolution meant, then the battle for its adoption would be rendered almost meaningless.

At least in the area of political activity, the framers and most of the supporters of the resolution apparently meant that any punishment of speech offenses must be left to the criminal courts. Thus even if a student incites his audience to riot on the steps of the administration building where the police could arrest the speaker if a "clear and present danger" developed-university discipline is still inappropriate. This construction makes the resolution important, meaningful, and controversial. Whether it is legally sound remains to be considered.

Two major lines of argument support the faculty resolution: First, in the areas with which the resolution deals, the special regulatory interests of the university seem adequately protected by the general law. If a student provokes a breach of the peace, or incites his audience to take over the administration building, or defames another member of the campus community, the university obviously has a strong interest in seeing his conduct punished and in deterring repetitions. But this interest differs only in degree from that of the general community; the dean and the district attorney seek to punish the offender for similar reasons, even if the sanctions available to them are quite different. It is chiefly in the "sex, beer, and cheating" cases that the university's special interests are different in kind as well as in degree from those of the general law, and are thus appropriately vindicated through independent action. Since offenses of this sort seldom involve "speech or advocacy," the university's power to add its discipline to the penalties of the general law would be unaffected by the faculty resolution. Even in speech cases, moreover, the resolution in no way prevents the university from filing the criminal complaint, or having campus police officers make the arrest. ${ }^{29}$

20 The ultimate answer to this question depends, of course, upon the allocation of power between the campus police and the state and local police. Presumably the campus officers of a private umiversity will be powerless to make arrests for violations of the general law. Even at the Berkeley campus of the University of California there has been considerable controversy over the extent to which the county and city police have (a) the legal authority and (b) the legal obligation to enforce the general law on the campus at their own initiative or that of persons other than university officials. The issue most recently arose in the form of 
All it demands is that the question of guilt, and any constitutional defenses, must be judged in a criminal court, and that the penalty imposed by the court should be exclusive.

Does the resolution leave the University powerless to impose its own discipline in all speech cases? Despite the unqualified language, at least one exception might be suggested though probably not contemplated by the framers. Perhaps where no provision of the general law covers the case, and the university interest is very strong, campus sanctions may be warranted. On the other hand, where the general law does cover the case, and the offender is prosecuted and acquitted, even though there is clearly no double jeopardy, the university should not impose its own punishment.

The hardest case remains: Suppose that an offender is given a mild sentence by a criminal court for some very serious infraction of university rules. Perhaps, if nothing more, the university might bear the offense $\mathrm{n}$ mind when the offender subsequently seeks permission to use scarce university facilities for a speech, demonstration, rally, or meeting. While any sucl sanction is arguably a restriction of the content of speech, it may be justified to preserve order on the campus and keep the channels of communication freely available to all applicants.

A consideration of procedures also underscores the soundness of the faculty resolution. An administrative tribunal within a university is not, by definition, a court. The presiding officer lacks the independence and detachment of a judge, even if lie enjoys academic tenure. Few of the essential guarantees of the criminal process are typically provided in a disciplinary liearing-the right to counsel and full cross-examination, requirement of notice and specific charges, presumption of innocence, and the taking of a verbatim transcript. Nor is judicial review as readily available. $^{30}$ The difference in procedures acquires constitutional significance from the increasing suspicion of the courts toward use of nonjudicial proceedings to impose restraints upon expression and publi-

several bills submitted by local authorities to the University for expenses incurred in making arrests during the Sproul Hall sit-in of December 1964. The Regents have agreed to pay a bill of $\$ 4,580$ for police services provided by the City of Oakland, but not the bills of $\$ 2,170$ from the City of Berkeley and of $\$ 3,628$ from the County of Alameda. The General Counsel of the University takes the position that Berkeley and Alameda County law enforcement officers are not only authorized, but legally obligated, to enforce the general law on the campus, while the Oakland police came to the Berkeley campus only because the University requested their aid. San Francisco Chronicle, Feb. 20, 1965 p. 4, col. 3.

30 For appreciation of some of the difficulties involved in obtaining judicial review of state university disciplinary actions, even in the federal courts of a northern state, see Steier v. New York State Educ. Comm'r, 271 F.2d 13 (2d Cir. 1959), cert. denied, 361 U.S. 966 (1960); cf. Dunmar v. Ailes, 348 F.2d 51 (D.C. Cir. 1965); In re Carter, 262 N.C. 360,137 S.E.2d 150 (1964). For a more general discussion, sce Note, 72 YaLE L.J. 1362, 1392-95 (1963). 
cation. ${ }^{31}$ Such suspicion seems particularly appropriate in this context, both because of the high degree of constitutional protection to which political expression is entitled, and because of the great severity of the disciplinary sanctions which may be based upon the university hearing. Thus, although the first amendment does not flatly forbid resort to administrative hearings to regulate political speech, recent constitutional developments caution that such proceedings should be used very sparingly. ${ }^{32}$

\section{III}

\section{ON-CAMPUS ADVOCACY OF OFF-CAMPUS POLITICAI ACTION}

The faculty resolution declares that "off-campus student political activities" should be immune from university regulation, and that "oncampus advocacy" of such activity should be regarded only as to time, place, and manner in order to "prevent interference with the normal functions of the University." Any analysis of these precepts must begin by recognizing the artificiality and the parochialism of the distinction between what occurs "off-campus" and "on-campus." It is no longer

31 In several recent cases the United States Supreme Court has been particularly critical of the use of nonjudicial procedures to deter or restrict expression and communication. Most recently, in Freedman v. Maryland, 380 U.S. 51 (1965), the Court invalidated a motion picture censorship law which failed to (1) place the burden of proof on the censor; (2) fix a short time within which any ban must be dissolved if judicial review has not taken place; and (3) guarantee a pronipt and final judicial determination of the question of obscenity. Similar procedural deficiencies resulted in the striking down two years earlier of a Rhode Island system of informal administrative control of the distribution of books which might or might not be legally obscene. Bantan1 Books, Inc. v. Sullivan, 372 U.S. 58 (1963). In two recent cases, the Court has effectively precluded seizure of allegedly obscene materials before there has been an adversary judicial determination of the obscenity issue. A Quantity of Copies of Books v. Kansas, 378 U.S. 205 (1964); Marcus v. Search Warrant, 367 U.S. 717 (1961). It is true that these cases all involved prior restraints rather than subsequent punishments, but in matters of free expression that distinction deserves little constitutional deference. See Freund, The SUpreme Court of the United States 63 (1961).

32 A dramatic validation of these principles has recently come from a quite unexpected quarter-the selective service controversy. The Director of the Selective Service System took the position during the fall of 1965 that registrants might properly be reclassified 1-A as a penalty for certain illegal forms of demonstration against the draft (for example, sit-ins in local draft board offices). Early in 1966, however, Assistant Attorney General Fred M. Vinson, Jr., chief of the Criminal Division of the Justice Department, stated a contrary view. Mr. Vinson stressed that "as a matter of both law and policy, the sanctions of the Universal Military Training and Service Act cannot be used in any way to stifle constitutionally protected expression of views." His caution rested apparently on two points: (1) Enforcement of the general criminal law against the offender adequately protects the interests of the Selective Service System; and (2) a classification process is administrative, not legal. N.Y. Tines, Jan. 12, 1966, p. 1, col. 1; p. 8, col. 4 (city ed.). Thus the two essential premises of the Assistant Attorney General's caveat appear to be substantially the two inajor points urged here in support of the Academic Senate resolution. The comparability of the two contexts, and thus the pertinence of Mr. Vinson's argunent, slould be obvious. 
possible, as the framers must have been aware even while building the dichotomy into their resolution, to differentiate so sharply between what is "town" and what is "gown." The distinction persists because it is a useful analytical tool, not because it is necessarily grounded in logic or practical experience. Bearing this caveat in mind, one can interpret this section of the resolution: If a group of students uses campus facilities to organize a sit-in or demonstration off the campus, so long as they comply with campus time, place, and manner rules, they should not be punished even if the demonstration results in arrests. Nor should students arrested in the course of the sit-in be disciplined solely because of the arrest-at least so long as the demonstration comes under the heading of "political activity." These conclusions rest upon grounds similar to those underlying the more general declaration about university regulation of the content of on-campus advocacy.

Here too the special university interests seem adequately protected by enforcement of the general law. If the off-campus sit-in results in arrests, whoever on the campus advocated the demonstration may well be liable to arrest as a solicitor, aider and abettor, or co-conspirator. Proof that his speech created a clear and present danger of violence or mass law violations would foreclose first amendment defenses. ${ }^{34}$ To this extent the university's interests seem no different from those embodied in the general criminal law: If the organizer or advocate of the unlawful off-campus activity is prosecuted and convicted, the university's punitive and deterrent interests would seem to have been vindicated. And if the advocate is acquitted, then subsequent university discipline would seem unjustified absent a showing of some quite distinct set of interests.

A second factor which reinforces the faculty position is the great difficulty of determining the legality of the off-campus activity. The fact that demonstrators may have been arrested does not necessarily mean that they can constitutionally be convicted. ${ }^{35}$ And so long as there remain

\footnotetext{
${ }^{83}$ On the question of a university's power to discipline on such grounds, regardless of relevance to the university's special interests, compare Knight v. State Bd. of Educ., $200 \mathrm{~F}$. Supp. 174, 181 (M.D. Tenn. 1961), with Due v. Florida A. \& M. Univ., 233 F. Supp. 396 (N.D. Fla. 1963).

34 That is, one who organizes a demonstration may be convicted only upon a showing that his speech has created a clear and present danger. Cox v. Louisiana, 379 U.S. 536, 544-52 (1965); Edwards v. South Carolina, 372 U.S. 229, 235-38 (1963). Presumably the general law could impose no lesser sanction than a conviction-even of a nonpunitive sort, such as demanding that the speaker leave the scene of the meeting-absent proof of a clear and present danger.

85 In fact, all of the major sit-in cases which have so far reached the U.S. Supreme Court have eventually been reversed. E.g., Hamin v. City of Rock Hill, 379 U.S. 306 (1964); Bell v. Maryland, 378 U.S. 226 (1964); Bouie v. City of Columbia, 378 U.S. 347 (1964); Peterson v. City of Greenville, 373 U.S. 244 (1963); Lombard v. Louisiana, 373 U.S. 267 (1963); Garner v. Louisiana, 368 U.S. 157 (1961).
} 
serious constitutional questions about the prosecution of the active participants-as there are likely to be in the presently unsettled law of sit-ins and demonstrations $\mathrm{s}^{38}$-it would seem unfair if not unconstitutional to prejudge the guilt of the on-campus advocate. ${ }^{37}$ Discipline should therefore await the resolution of any substantial constitutional questions in the prosecutions of the off-campus actors. By that time the advocate is quite likely to have graduated or left the campus anyway. Thus the university's actual disciplinary power seems illusory, even if the legitimacy of its interest be conceded.

Finally, the matter of procedural safeguards is equally relevant here. If the advocate may be suspended or expelled by means of an administrative hearing, while punishment of the off-campus actors is to be relegated to the criminal courts, the result is paradoxical: Greater procedural safeguards accompany the imposition of a lesser penalty upon the actor than attend the imposition of a possibly greater penalty upon the speaker. If anything, the speaker should be entitled to more sensitive procedures than the actor even where the penalties are identical. ${ }^{38}$ And where harsher penalties may follow, the use of administrative proceedings to judge such issues as "clear and present danger," "incitement," and the like becomes particularly hazardous. The faculty resolution urges that such discipline should be left to the courts precisely because of these hazards.

This proposition carries one important corollary, however: If the university is not to impose independent discipline in such cases, then the walls of the university should afford no sanctuary from enforcement of the general law. If, for example, the off-campus demonstration does cause destruction of property, the advocate should enjoy no greater immunity

80 For discussion of some of the complexities and uncertainties of the sit-in litigation, see, e.g., Lewis, The Sit-in Cases: Great Expectations, 1963 Sur. CT. REv. 101; Rice, Sit-Ins Proceed With Caution, 29 Mo. L. REv. 39 (1964); Schwelb, The Sit-In Demonstration: Criminal Trespass or Constitutional Right?, 36 N.Y.U.L. REv. 779 (1961); Wright, Public ACcommodations-The Sit-in Movement, Progress Report and Proposals, in LEGal Aspects of THE CrviL RigHts Movement 87 (King \& Quick eds. 1965).

37 Cf. Shuttlesworth v. City of Birmingham, 373 U.S. 262 (1963), in which the Court reversed two convictions for aiding and abetting a violation of the Birmingham criminal trespass law. The Court found this result compelled by its reversal, on the same day, of the trespass convictions of Negro students whom the petitioners in the Shuttlesworth case had incited to demonstrate. Relying upon a long line of precedent, the Court concluded that "there can be no conviction for aiding and abetting someone to do an innocent act." Id. at 265; cf. NAACP v. Button, 371 U.S. 415, 431-38 (1963).

38 In other contexts, notably labor picketing, the Supreme Court has suggested that picketing, being "more than inere speech" or "speech combined with action," is less entitled to constitutional protection than "pure speech." See, e.g., Giboney v. Empire Storage \& Ice Co., 336 U.S. 490, 497-503 (1949); Bakery Drivers' Local 802 v. Wohl, 315 U.S. 769, 776-77 (1942) (Douglas, J., concurring) ; cf. Schwartz-Torrance Inv. Corp. v. Bakery Workers' Union, 61 Cal. 2d 766, 394 P.2d 921, 40 Cal. Rptr. 233 (1964). See generally Rosen, The Law and Racial Discrimination in Employment, 53 CALIF. L. REv. 729, 765-68 (1965). 
than one who organizes such a demonstration in a public park. There remains, of course, the difficult decision as to which legal entity is to enforce the general law on the campus-whether university or city or county police-but that is a matter traditionally resolved by local law. Nothing in the faculty statement suggests any position on that question.

\section{IV}

REGULATION OF "TTME, PLACE, AND MANNER"

The December 8 resolution clearly recognized the necessity of university regulation in the realm of time, place, and manner of political activity on the campus. A university must be able to supervise such incidents of the speech situation-not only to ensure quiet and orderly flow of traffic and other conditions essential to a productive academic community, but also to guarantee the fair distribution of scarce rostra and anplification equipment. There is no constitutional doubt about the legitimacy of these interests; indeed, such restrictions are appropriate even in the more "public" village square and city park..$^{30}$ Yet there are several obvious dangers in the recognition and implementation of these interests.

Although "time" and "place" are easy enough to define, "manner" is a rather vague term. It could provide the handle for regulation of speech content under the guise of ostensibly procedural restrictions. To avoid this abuse, "manner" should be understood to denote only those physical and procedural incidents of public expression that are neither "time" nor "place"-for example, the size and number of posters that can be displayed in certain locations, the volume of sound amplification, chairmanship of public meetings, identification of persons soliciting funds, methods of distributing literature, and the myriad other matters that must be regnlated in order effectively to regulate the speech situation. With this understanding, reference to "manner" should provide no invitation to veiled censorship.

It goes without saying that time, place, and manner limitations should be reasonable-that is, they should go no further than necessary "to prevent interference with the normal functions of the university." 40 The administration should not close off all the effective channels of communication, or those which are readily accessible to small groups, or to

${ }^{39}$ See Cox v. Louisiana, 379 U.S. 536, 554-55 (1965).

40 This qualification seems merely to restate the doctrine of the "least onerous alternative," discussed at note 27 supra. Arguably any regulations of the speech situation which went beyond the limits necessary to prevent interference with the normal functions of the university would not be time, place, and manner rules anyway; but the Academic Senate wished to foreclose any such controversy by the addition of this qualifying phrase. 
certain undergraduate political groups that cannot afford elaborate facilities, or to the graduate students or commuting students. ${ }^{11}$

"Reasonable" has another aspect as well. Time, place, and manner rules should be nondiscriminatory-that is, should not disadvantage particular classes of expression on arbitrary grounds, for this too may constitute a veiled form of content regulation. For example, the university as "landlord" may well be able to prohibit all use of dormitory windows for display of signs and banners. But if it permits signs reading "Beat Stanford" it may not ban physically similar signs urging "Beat the Viet Cong" or "Beat Ronald Reagan." Nor should the university permit distribution on the campus of a safe, politically neutral or conservative student newspaper while banning dissemination of the abrasive or disquieting publications of a student protest group. In these cases freedoin of speech and of the press may well not require any access to campus facilities. But if facilities are made available for any purposes, then they must be offered on equal terms to all similarly qualified groups. ${ }^{42}$

This brief discussion suggests that while the constitutional issues underlying the December 8 resolution are far from settled, there is respectable legal support for the position taken by the Academic Senate. Against the background of developing constitutional law, it seems preferable to leave all control of speech content to the criminal courts and the general law if only because the procedural safeguards are more rigorous than those of the academic administrative hearing. Moreover, the university's admittedly strong special regnlatory interests are either not of a sort to inhibit freedom of expression and are thus not affected by the faculty resolution, or are usually adequately served by enforcement of the general law. Finally, to the extent that the general law may not fully serve the special university interests, the faculty resolution does call for reasonable regulation of the time, place, and manner of speaking on the campus. The Berkeley faculty thus recommends that state uni-

41 Cf. Wollam v. City of Palm Springs, 59 Cal. 2d 276, 284-85, 379 P.2d 481, 486, 29 Cal. Rptr. 1, 6 (1963). The Califorma Supreme Court noted in that case the importance of particular means of communication to particular groups with particular messages: "In certain instances the sound truck may be the only practical means for communication of opinion; alternative modes of communication, such as radio and television, may be prohibitively expensive, not available, or not effective. . . The loss of the loud speaker thus becomes a curtailment of the recognized right of the union to publicize effectively its cause at the job site." Id. at 284, 379 P.2d at 486, 29 Cal. Rptr. at 6 . The court also offered a more general statement of the point: "The right to speak freely must encompass inherently the right to commumicate. The right to speak one's views aloud, restricted by a ban that prevented anyone from listening, would frame a hollow right. Rather, freedom of speech entails comnunication; it contemplates effective commumication." Ibid.

42 Danskin v. San Diego Unified School Dist., 28 Cal. 2d 536, 547, 171 P.2d 885, 892 (1946); Van Alstyne, Political Speakers at State Universities: Some Constitutional Considerations, 111 U. PA. L. REv. 328, 337-39 (1963). 
versity administrators should concentrate their rule-making skills on the task of framing workable time, place, and manner rules, and leave the content of expression alone. That is what has in fact occurred on the Berkeley campus in the year since the adoption of the resolution. ${ }^{43}$

43 Chancellor Roger W. Heyns of the Berkeley Campus of the University of California issued, on September 16, 1965, a set of provisional rules governing (1) registration of student organizations; (2) use of University facilities; (3) the time, place, and manner of public expression; and (4) procedural fairness in student discipline cases. Daily Californian, Sept. 16, 1965, pp. 6-7. These rules were designed to implement for the Berkelcy campus the Universily of California Policies Relating to Student Conduct, Student Organizations, Use of Universily Facilities, and Non-discrimintation, adopted by the Regents of the University of California at their June meeting. These Policies became effective for all campuses on July 1, 1965. University Bulletin, Umiversity of California, June 29, 1965, p. 271. Chancellor Heyns has announced plans for the promulgation of a final set of campus rules during the current academic year. To aid in that task a Campus Rules Committee, advisory to the Chancellor, has been designated and will meet on matters concerning the rules during the spring of 1966. 